\title{
The Research is about the Follow-up Effect on City and Society which was Exerted by World Expo based on the Investigation of Inhabitants' Perception in Shanghai
}

\author{
Yang Shunyong, Zhao Jinjie and Cao Yang* \\ Shanghai Institute of Technology, Shanghai 201418, P. R. China
}

Received: 6 Jun. 2013, Revised: 11 Oct. 2013, Accepted: 12 Oct. 2013

Published online: 1 May. 2014

\begin{abstract}
This report regarded Shanghai habitants as research targets on the foundation of a survey about the follow-up effect on city and society which was exerted by 2010 world Expo. 1213 Shanghai habitants had been interviewed during the measurement. After having analyzed the factors, we found that the World Expo had a strong follow-up effect on the society. It mainly enhanced the notability of Shanghai all over the world, promoted the communication in the field of science, technology and culture. Moreover, it established the image of Shanghai as 'city of MICE' and enriched cultural knowledge about different places. We can find out abundant resources of the World Expo, at the same time, we can make the world know more about China. You can experience different customs and culture from different countries/places and the resources overseas. In addition, it had an educational effect on local habitants and it helped to protect and promote Chinese culture. It also contributed to enhance the relationships among the habitants, visitors and tourists. You could also enjoy a novel experience. Last but not least, people would have opportunities to witness both the positive factors from lots of performance in the Expo and negative factors from the increasing crime rate, the conflicts between the inside and outside and the negative impact which the traditional culture have suffered from. The cluster analysis fully demonstrated that the positive follow-up effect of the World Expo on city and society was recognized by the habitants who had been interviewed while the negative ones were realized as well. Thus, relative administration sections of the Shanghai government should make effective public policies without delay, lead the enduring development of the positive follow-up effect of the World Expo, and minimize the negative effect at large
\end{abstract}

Keywords: Shanghai World Expo,the follow-up effect,city \& society,Perception.

\section{Introduction}

Recently, the scholars from both home and abroad did more researches on such events as the Olympic Games and the World Cup than on the World Expo. There are few relative topics about the social effects which local inhabitants made on the Expo. For example, Maurice Roche(1995)thought that if the events could be held successfully, positive image of the host city would be renewed by media report, tourism and outside investment.The change of crime rate, which has been researched by M. Barker and his team(2002), showed that local crime rate increased indistinctly. Choong-Ki Lee(2005)and his team has investigated the effects of big events on the image of tour destination. The 41th World Expo,the first Expo which was marked into the history by the most extensive level of participation,was held by China. 190 countries, 56 international organizations and
73.08 million visitors were all hooked and fascinated by that. Thus, the success of the 2010 World Expo is meaningful to the development of Shanghai. It must exert profound effects on economy, social culture, city environment and other aspects of Shanghai. Although it has made many positive effects, it also brought about some negative ones. Shanghai inhabitants, as the direct undertakers of its follow-up effect, their support would guarantee the enduring proliferation of the positive follow-up effect of the World Expo. Therefore, it is of great significance and reality value to investigate inhabitants' perception about the follow-up effect of the World Expo2010.

\footnotetext{
*Corresponding author e-mail: caoyang @ sit.edu.cn
} 


\section{Research Design}

\subsection{Questionnaire}

The first part of questionnaire is the demography and the variability of the social attribute from the respondents which including sex, age, education background, profession, monthly pay and length of stay. The second part is the respondents' perception to the follow-up effect of the World Expo2010, its questions consist of enhancing the notability of Shanghai all over the world, promoting the communication in the field of science, technology and culture, establishing the image of Shanghai as 'city of MICE', enriching cultural knowledge about different places, finding out abundant resources of the World Expo, making the world know more about China, experiencing different customs and culture from sorts of countries and the resources overseas, educational effects on local inhabitants and its help to the protection and promotion of Chinese culture, improving the relations among the inhabitants, visitors and tourists, enjoying novel experience, having opportunities to appreciate performance, increasing crime rate, the conflicts between the inside and outside, the negative impact which the traditional culture have suffered from. The cluster analysis fully demonstrated that the positive follow-up effect of the World Expo on city and society was recognized by the habitants who had been interviewed while the negative ones were realized as well. People should judge different levels by five projects in the Likert inventory, and 1-5 respectively stand for 'completely disagree', 'disagree', 'not sure', 'agree' and 'can't agree more'.

\subsection{Data resource}

We used stochastic sampling to start the investigation. 1500 questionnaires were delivered to Shanghai inhabitants on November 1st, 2011, one year of the World Expo, which resulted in $87.5 \%$ (1312) sample return and $92.5 \%$ (1213) is effective. As a whole, the characteristics of inhabitants who were interviewed (as it shown in table 1) are basically consistent with the demographic characteristics of Shanghai inhabitants. It is of a high randomness and our investigation data is a typical representative.

\section{Analysis and Discussion}

\subsection{Test of questionnaire's reliability}

We used the software SPSS18.0 to test the reliability of data collected in the investigation the Cronbach $\alpha$ of the questionnaire is 0.947 , it shows that the questionnaire has a good and steady homogeneity reliability; The related coefficient of its structure is between 0.171 and 0.835 ,and every item reaches to significant level,it demonstrates that the questionnaire has excellent validity; Its KMO test value is 0.954 , the significance probability of Bartlett roundness inspection is 0 ,it illustrates that the correlation matrixes are not identity matrixes, so all of them could be used to do factor analysis and cluster analysis,they all conform to the design requirement.

\subsection{Descriptive Statistics}

Firstly, we have sorted out 1213 valid questionnaires and then got the primary statistics result of the respondents perception to the follow-up effect of the World Expo2010, as it shown in Table 2:

Then we use the software SPSS18.0 to get inhabitants' apperceive variables about the follow-up effect of the World Expo including descriptive statistical results of minimum,maximum,medium value,standard deviation and variance, as it shown in Table 3:

Table 3 has shown the statistics result of the respondents' perception to the follow-up effect of the Shanghai World Expo. From the form We can see that single average mark of perception is more than entire mark of perception 3.7540,the evaluating indicator of this statistics including 11 items: Enhancing the notability of Shanghai all over the world, Promoting the communication in the field of science, technology and culture, Establishing the image of Shanghai as 'city of MICE', Enriching cultural knowledge about different countries/places, Finding out abundant resources of the World Expo, Making the world know more about China, Experiencing different customs and culture from different countries/places, Experiencing different resources overseas, Helping to protect and promote Chinese culture, Enjoying a novel experience, Having opportunities to appreciate the positive factors from lots of performance in the Expo. Because the respondents think that these 11 items of perception are most significant and they are the vital items of the follow-up effect of the Shanghai World Exp. Their influences are great and deep. So the Expo sponsors and policy makers will focus on them intensively.

\subsection{Factor Analysis}

We used the software SPSS18.0 to investigate and collect the data. Principal component analysis can help us to make sure the number of common factor and its factor loading, then according to the standard of maximizing the variance, we do the factor orthogonal rotation, after the rotation ,there came the results in Table 4.

According to Form4 we can see that measuring scale has extracted common factors from the initial form. The common factor F1 has a high normal load in the fields of 
Table 1: Structure characteristics of inhabitants who were interviewedsample size $n=1213$

\begin{tabular}{|c|c|c|c|}
\hline \multicolumn{2}{|l|}{ Respondent } & \multirow{2}{*}{$\begin{array}{l}\text { Person-time } \\
646\end{array}$} & \multirow{2}{*}{$\begin{array}{l}\text { Percentage } \\
53.26 \%\end{array}$} \\
\hline & Man & & \\
\hline Sex & Woman & 567 & $46.74 \%$ \\
\hline \multirow{5}{*}{ Age } & 17 Years Or Less & 35 & $2.89 \%$ \\
\hline & 18-24 Years & 585 & $48.23 \%$ \\
\hline & 25-44 Years & 306 & $25.23 \%$ \\
\hline & 45-64 Years & 246 & $20.28 \%$ \\
\hline & More Than 65 Years & 41 & $3.38 \%$ \\
\hline \multirow{4}{*}{ Education Background } & Junior Or Below & 79 & $6.51 \%$ \\
\hline & High school, Diploma & 164 & $13.52 \%$ \\
\hline & Junior College, Bachelor & 881 & $72.63 \%$ \\
\hline & Master Or Above & 89 & $7.34 \%$ \\
\hline \multirow{5}{*}{ Profession } & Enterprise Institution Staff & 482 & $39.74 \%$ \\
\hline & Professionals And Technical & 177 & $14.59 \%$ \\
\hline & Student & 400 & $32.98 \%$ \\
\hline & Retired & 51 & $4.2 \%$ \\
\hline & Else & 103 & $8.49 \%$ \\
\hline \multirow{5}{*}{ Monthly Pay } & 2000 Yuan Or Less & 165 & $13.6 \%$ \\
\hline & 2000-3500 Yuan & 417 & $34.38 \%$ \\
\hline & 3500-5000 Yuan & 321 & $26.46 \%$ \\
\hline & $5000-6500$ Yuan & 155 & $12.78 \%$ \\
\hline & More Than 6500 Yuan & 155 & $12.78 \%$ \\
\hline \multirow{4}{*}{ Length Of Stay } & 3 Years Or Less & 167 & $13.77 \%$ \\
\hline & 4-10 Years & 166 & $13.69 \%$ \\
\hline & $11-20$ Years & 152 & $12.53 \%$ \\
\hline & More Than 20 Years & 728 & $60.02 \%$ \\
\hline
\end{tabular}

enhancing the notability of Shanghai all over the world, promoting the communication in the field of science, technology and culture, establishing the image of Shanghai as 'city of MICE', enriching cultural knowledge about different countries/places, finding out abundant resources of the World Expo, making the world know more about China, experiencing different customs and culture from different countries/places ,experiencing different resources overseas, educational effect on local inhabitants, helping to protect and promote Chinese culture ,enhancing the relationships among the inhabitants, visitors and tourists, enjoying a novel experience having opportunities to appreciate the positive factors from lots of performance in the Expo. These norms have all increased development of the city and society in Shanghai as positive factors. The common factor F2 has a high normal load in the fields of increasing crime rate, the conflicts between the inside and outside, the negative impact which the traditional culture suffered from. These norms have affected the level of city and society in Shanghai as negative factors.

\subsection{Cluster Analysis}

We used Microsoft SPSS18.0 to do 5 kinds of cluster analyses. We also Investigated and collected the data to do variance test. We found that all the norm of variance significance were 0 . They demonstrated different sort of remarkable difference and they were all confirmed to the statistics significance requirement. The results of cluster analysis have been shown in Table 5 .

Clustering I $(2.4 \%$,Sample $n=29)$ : Objectors. This kind of inhabitants is objected to both positive factors and negative ones of follow-up effect which the World Expo 2010 made. After observing the typical value, we could also find that they gave the lowest mark to all the perception of the follow-up social effect of the World Expo2010,they denied the follow-up effect of the World Expo to the city and society in Shanghai, but the number of people is the least.

Clustering $(31.7 \%$,Sample n=384)Paradoxical Supporters. This kind of inhabitants keep paradoxical attitude to both positive factors and negative ones of follow-up effect which the World Expo 2010 made, all of value is balanced which is between 3.0 and 3.5.

Clustering $39.5 \%$,Sample $\mathrm{n}=479)$ Negative Supporters. This kind of inhabitants show agreement to positive factors of follow-up effect which the World Expo 2010 made and they are basically agree to the negative ones. It showed that they were negative Supporters as a whole and the number of people is the largest.

Clustering IV $(14.0 \%$,Sample $n=170)$ Rational Supporters. This kind of inhabitants show agreement to 
Table 2: The primary statistics result of the respondents' perception to the follow-up effect of the World Expo2010(sample size $\mathrm{n}=1213$ )

\begin{tabular}{|c|c|c|c|c|c|}
\hline Norm $\$ Perception & $\begin{array}{l}\text { Completely } \\
\text { Disagree }\end{array}$ & Disagree & Not Sure & Agree & $\begin{array}{c}\text { Can't Agree } \\
\text { More }\end{array}$ \\
\hline $\begin{array}{c}\text { Enhancing the notability of Shanghai } \\
\text { all over the world } A_{1}\end{array}$ & $23(1.9 \%)$ & $14(1.15 \%)$ & $230(18.96 \%)$ & $530(43.69 \%)$ & $416(34.3 \%)$ \\
\hline $\begin{array}{l}\text { Promoting the commurication in the } \\
\text { field of science, technology and } \\
\text { culture } A_{2}\end{array}$ & $22(1.81 \%)$ & $22(1.81 \%)$ & $263(21.68 \%)$ & $557(45.92 \%)$ & $349(28.77 \%)$ \\
\hline $\begin{array}{l}\text { Establishing the image of Shanghai as } \\
\text { 'city of MICE'A }\end{array}$ & $28(2.31 \%)$ & $30(2.47 \%)$ & $303(24.98 \%)$ & $530(43.69 \%)$ & $322(26.55 \%)$ \\
\hline $\begin{array}{l}\text { Enriching cultural knowledge about } \\
\text { different countries/places } A_{4}\end{array}$ & $25(2.06 \%)$ & $18(1.48 \%)$ & $258(21.27 \%)$ & $567(46.74 \%)$ & $345(28.44 \%)$ \\
\hline $\begin{array}{l}\text { Finding out abundart resources of the } \\
\text { World Expo } \mathrm{A}_{\text {s }}\end{array}$ & $25(2.06 \%)$ & $21(1.73 \%)$ & $285(23.5 \%)$ & $556(45.84 \%)$ & $326(26.88 \%)$ \\
\hline $\begin{array}{l}\text { Making the world know more about } \\
\text { China } \mathrm{A}_{6} \text {. }\end{array}$ & $26(2.14 \%)$ & $30(2.47 \%)$ & $250(20.61 \%)$ & $551(45.42 \%)$ & $356(29.35 \%)$ \\
\hline $\begin{array}{l}\text { Experiencing different customs and } \\
\text { culture from different courtriesiplaces } \\
\qquad \mathrm{A}_{7}\end{array}$ & $26(2.14 \%)$ & $32(2.64 \%)$ & $260(21.43 \%)$ & $564(46.5 \%)$ & $331(27.29 \%)$ \\
\hline $\begin{array}{l}\text { Experiencing different resources } \\
\text { owerseas } \mathrm{A}_{S}\end{array}$ & $23(1.9 \%)$ & $38(3.13 \%)$ & $308(25.39 \%)$ & $546(45.01 \%)$ & $298(24.57 \%)$ \\
\hline $\begin{array}{l}\text { Educational effect on local inhabitarts } \\
\qquad A_{9}\end{array}$ & $37(3.05 \%)$ & $66(5.44 \%)$ & $370(30.5 \%)$ & $478(39.41 \%)$ & $262(21.6 \%)$ \\
\hline $\begin{array}{l}\text { Helping toprotect and promote } \\
\text { Chinese culture } \hat{A}_{10}\end{array}$ & $32(2.64 \%)$ & $57(4.7 \%)$ & $329(27.12 \%)$ & $536(44.19 \%)$ & $259(21.35 \%)$ \\
\hline $\begin{array}{l}\text { Exhancing the relationships arnong the } \\
\text { inhlabitants, visitos and tourists } \mathrm{A}_{11}\end{array}$ & $29(2.39 \%)$ & $60(4.95 \%)$ & $366(30.17 \%)$ & $490(40.4 \%)$ & $268(22.09 \%)$ \\
\hline Enjoying a novel experience $A_{12}$ & $23(1.9 \%)$ & $24(1.98 \%)$ & $333(27.45 \%)$ & $546(45.01 \%)$ & $287(23.66 \%)$ \\
\hline $\begin{array}{l}\text { Having opportumities to appreciate the } \\
\text { positive factors from lots of } \\
\text { performance in the Expo } \mathrm{A}_{1}\end{array}$ & $21(1.73 \%)$ & $33(2.72 \%)$ & $308(25.39 \%)$ & $545(44.93 \%)$ & $306(25.23 \%)$ \\
\hline Increasing crime rate $A_{14}$ & $79(6.51 \%)$ & $267(22.01 \%)$ & $428(35.28 \%)$ & $260(21.43 \%)$ & $179(14.76 \%)$ \\
\hline $\begin{array}{l}\text { The conflicts between the inside and } \\
\text { outside } A_{1} \text { s }\end{array}$ & $78(6.43 \%)$ & $279(23 \%)$ & $414(34.13 \%)$ & $258(21.2 \%)$ & $184(15.1 \%)$ \\
\hline $\begin{array}{l}\text { The negative impact which the } \\
\text { traditional culture suffered from } \mathrm{A}_{1} \text {, }\end{array}$ & $82(6.76 \%)$ & $271(22.34 \%)$ & $468(38.58 \%)$ & $220(18.14 \%)$ & $172(14.18 \%)$ \\
\hline
\end{tabular}

positive factors of follow-up effect which the World Expo 2010 made and they are basically agree to the negative ones. From the form5 we could see that the description which they completely agree ( medium value 33.8 ) were all positive factors. Thus, they were rational and realistic supporters.

Clustering(12.4\%,Sample $\mathrm{n}=151)$ Enthusiastic supporters. The perception of this kind of inhabitants were the most sensitive to both positive factors and negative ones of follow-up effect which the World Expo 2010 made. They gave the highest mark to all the perception of the follow-up social effect of the World Expo2010.They admitted that when they were benefit from the Expo, they also paid more attention to the cost.

\section{Conclusions}

The report was based on the data which had been collected from 1213 Shanghai inhabitants who joined the investigation of perception to the follow-up effect on city and society in Shanghai, one year after the World Expo 2010, and then we did several analysis on it. The results showed that the follow-up effect of the World Expo 2010 was mainly enslaved to two factorspositive factorsenhancing the notability of Shanghai all over the world, promoting the communication in the field of science, technology and culture, establishing the image of Shanghai as 'city of MICE', enriching cultural knowledge about different countries/places, finding out abundant resources of the World Expo, making the world know more about China, experiencing different customs and culture from different countries/places, experiencing different resources overseas, educational effect on local inhabitants, helping to protect and promote Chinese culture, and negative factors(enhancing the relationships among the inhabitants, visitors and tourists, enjoying a novel experience, having opportunities to appreciate the positive factors from lots of performance in the ExpoThe 
Table 3: Inhabitants' apperceive variables about the follow-up effect of the World Expo2010 (

\begin{tabular}{|c|c|c|c|c|c|c|}
\hline \multirow{2}{*}{ Apperceive Variables } & \multirow{2}{*}{$\begin{array}{r}\text { Minimum } \\
\text { Statistic }\end{array}$} & \multirow{2}{*}{\begin{tabular}{|l|} 
Maximem \\
Statis tic
\end{tabular}} & \multicolumn{2}{|c|}{ Medium Value } & \multirow{2}{*}{\begin{tabular}{|c|}
$\begin{array}{l}\text { Standard } \\
\text { Deviation }\end{array}$ \\
Statis tic \\
\end{tabular}} & \multirow{2}{*}{$\begin{array}{l}\text { Variance } \\
\text { Statis tic }\end{array}$} \\
\hline & & & Statistic & $\begin{array}{l}\text { Standard } \\
\text { Error }\end{array}$ & & \\
\hline $\begin{array}{l}\text { Enhameing the notability of } \\
\text { Shanghai alloverthe world A }\end{array}$ & 100 & 500 & 40734 & .02478 & .86291 & .745 \\
\hline $\begin{array}{c}\text { Fromoting the cormrnuication in } \\
\text { the field of scierce, tecknology } \\
\text { and culture } A\end{array}$ & 100 & 500 & 39800 & .02471 & .80054 & .741 \\
\hline $\begin{array}{c}\text { Establishing the image of } \\
\text { Shanghai as 'dity of MICE'A }\end{array}$ & 100 & $5 \infty 0$ & 38969 & .02587 & .90110 & .812 \\
\hline $\begin{array}{l}\text { Erriching cultural knowledze } \\
\text { about different oourtries/places } \\
\text { A }_{4}\end{array}$ & 100 & 500 & 39802 & .02474 & .86150 & .742 \\
\hline $\begin{array}{c}\text { Finding out abundant resources } \\
\text { of the World Expo A }\end{array}$ & 100 & 500 & 39373 & .02495 & .86899 & .755 \\
\hline $\begin{array}{c}\text { Makingthe world know more } \\
\text { about China } \mathrm{A}\end{array}$ & 100 & 500 & 39736 & .02554 & .80900 & .791 \\
\hline $\begin{array}{l}\text { Experiencing different customs } \\
\text { and culture from different } \\
\text { countries/places } \mathrm{A}\end{array}$ & 100 & 500 & 39415 & .02540 & .8480 & .783 \\
\hline $\begin{array}{c}\text { Experiencing different resources } \\
\text { overseas } A\end{array}$ & 100 & 500 & 38722 & .02536 & .88310 & .700 \\
\hline $\begin{array}{c}\text { Educational effect on boal } \\
\text { inhabitants } A\end{array}$ & 100 & $5 \infty 0$ & 3.7105 & .02769 & .96448 & .930 \\
\hline $\begin{array}{l}\text { Helping to protect and promote } \\
\text { Chinese culture } A\end{array}$ & 100 & 500 & 3.7692 & .00550 & .92505 & .858 \\
\hline $\begin{array}{l}\text { Erhancing the relationships } \\
\text { among the mhabitants, visitors } \\
\text { and tourits A }\end{array}$ & 100 & 500 & 3.7486 & .00583 & .93445 & .873 \\
\hline Enjoying a novel experienoe $A$ & 100 & 500 & 38656 & .00476 & .86225 & .743 \\
\hline $\begin{array}{l}\text { Having oppontumities to } \\
\text { appreciate the positive factors } \\
\text { from bts of perfomance in the } \\
\text { Expo A }\end{array}$ & 100 & 500 & 38920 & .02503 & .87165 & .760 \\
\hline Increasing crime rate $A_{A}$ & 100 & 500 & 3.1591 & .03224 & 1.12293 & 1251 \\
\hline $\begin{array}{c}\text { The oonflicts between the inside } \\
\text { and outside } A\end{array}$ & 100 & 500 & 3.1575 & .03252 & 1.13257 & 1283 \\
\hline $\begin{array}{l}\text { The negative irmact which the } \\
\text { traditional culture suffered form } \\
\text { A }\end{array}$ & 100 & 500 & 3.1063 & .03187 & 1.10999 & 1232 \\
\hline
\end{tabular}

Table 4: Getting the result after the rotation (sample size $\mathrm{n}=1213$ )

\begin{tabular}{|c|c|c|}
\hline Apperceive Variahles & \multicolumn{2}{|c|}{ Common Factor } \\
\hline & $\mathbf{F}_{1}$ & $\mathbf{F}_{2}$ \\
\hline Enhancing the notability of Shanghai all over the world $\mathrm{A}_{1}$ & 830 & \\
\hline Promoting the communication in the field of science, technology and culture $\mathrm{A}_{2}$ & .866 & \\
\hline Establishing the image of Shanghai as 'city of MICE' $\mathrm{A}_{3}$ & .852 & \\
\hline Enriching cultural knowledge about different countries/places $\mathrm{A}_{4}$ & 887 & \\
\hline Finding out abundant resources of the World Expo $\mathrm{A}_{5}$ & .886 & \\
\hline Making the world know more about China $\mathrm{A}_{6}$ & .883 & \\
\hline Experiencing different customs and culture from different countries/places $\mathrm{A}_{7}$ & .865 & \\
\hline Experiencing different resources overseas $\mathrm{A}_{8}$ & .855 & \\
\hline Educational effect on local inhabitants $\mathrm{A}_{9}$ & .800 & \\
\hline Helping to protect and promote Chinese culture $\mathrm{A}_{10}$ & .819 & \\
\hline Enhancing the relationships among the inhabitants, visitors and tourists $\mathrm{A}_{11}$ & 795 & \\
\hline Enjoying a novel experience $\mathrm{A}_{12}$ & .814 & \\
\hline Having opportunities to appreciate the positive factors from lots of performance \\
in the Expo $\mathrm{A}_{13}$ & 776 & \\
\hline Increasing crime rate $\mathrm{A}_{14}$ & & .914 \\
\hline The conflicts between the inside and outside $\mathrm{A}_{15}$ & .928 \\
\hline The negative impact which the traditional culture suffered from $\mathrm{A}_{16}$ & & .905 \\
\hline
\end{tabular}


Table 5: Result of measuring scale cluster analysis (

\begin{tabular}{|c|c|c|c|c|c|}
\hline Variable of perception & Cluster I & Cluster II & Cluster III & $\begin{array}{l}\text { Cluster } \\
\text { IV }\end{array}$ & $\begin{array}{c}\text { Cluster } \\
v\end{array}$ \\
\hline $\begin{array}{c}\text { Enhancing the notability of Shanghai all } \\
\text { over the world } A_{1}\end{array}$ & 1.3793 & 3.5313 & 4.0856 & 4.9059 & 4.9934 \\
\hline $\begin{array}{l}\text { Promoting the communication in the } \\
\text { field of science, technology and culture } \\
\qquad \mathrm{A}_{2}\end{array}$ & 1.4138 & 3.3568 & 4.0167 & 4.8353 & 4.9801 \\
\hline $\begin{array}{l}\text { Establishing the image of Shanghai as } \\
\text { 'city of MICE' } A_{3}\end{array}$ & 1.2759 & 3.2240 & 3.9541 & 4.7471 & 4.9735 \\
\hline $\begin{array}{l}\text { Enriching cultural knowledge about } \\
\text { different countries/places. }\end{array}$ & 1.2414 & 3.3281 & 4.0459 & 4.8824 & 4.9404 \\
\hline $\begin{array}{l}\text { Finding out abundant resources of the } \\
\text { World Expo As }\end{array}$ & 1.2069 & 3.2969 & 3.9708 & 4.8412 & 4.9669 \\
\hline $\begin{array}{c}\text { Making the world know more about } \\
\text { China } A_{6}\end{array}$ & 1.1379 & 3.3229 & 4.0313 & 4.8882 & 4.9603 \\
\hline $\begin{array}{l}\text { Experiencing different customs and } \\
\text { culture from different countries/places } \\
\qquad \mathrm{A}_{7}\end{array}$ & 1.2759 & 3.2969 & 3.9770 & 4.8294 & 4.9801 \\
\hline $\begin{array}{c}\text { Experiencing different resources } \\
\text { overseas } \mathrm{A}_{8}\end{array}$ & 1.3103 & 3.2318 & 3.9019 & 4.6941 & 4.9735 \\
\hline $\begin{array}{c}\text { Educational effect on local inhabitants } \\
\text { Ag }\end{array}$ & 1.2069 & 2.9896 & 3.8163 & 4.3471 & 4.9735 \\
\hline $\begin{array}{c}\text { Helping to protect and promote Chinese } \\
\text { culture } \mathrm{A}_{10}\end{array}$ & 1.1034 & 3.0781 & 3.8852 & 4.3882 & 4.9735 \\
\hline $\begin{array}{l}\text { Enhancing the relationships among the } \\
\text { inhabitants, visitors and tourists } A_{11}\end{array}$ & 1.2759 & 3.0417 & 3.8914 & 4.2824 & 4.9669 \\
\hline Enjoying a novel experience $\mathrm{A}_{12}$ & 1.3793 & 3.2552 & 3.9478 & 4.4471 & 4.9801 \\
\hline $\begin{array}{c}\text { Having opportunities to appreciate the } \\
\text { positive factors from lots of } \\
\text { performance in the Expo } A_{13}\end{array}$ & 1.6207 & 3.2995 & 3.9687 & 4.4412 & 4.9735 \\
\hline Increasing crime rate $A_{14}$ & 1.9655 & 3.1068 & 3.0376 & 2.2588 & 4.9205 \\
\hline $\begin{array}{l}\text { The conflicts between the inside and } \\
\text { outside } A_{15}\end{array}$ & 2.0000 & 3.1667 & 2.9937 & 2.2294 & 4.9205 \\
\hline $\begin{array}{l}\text { The negative impact which the } \\
\text { traditional culture suffered from } A_{16}\end{array}$ & 1.8276 & 3.0339 & 2.9645 & 2.2588 & 4.9404 \\
\hline
\end{tabular}

inhabitants who were interviewed have affirmed both the positive and negative follow-up effects of the World Expo 2010. As a result, government of Shanghai should make effective public policies without delay. In addition, they should launch publicity propaganda on purpose, carry out some effective measures concerning improvement, increase interaction and understanding between the inhabitants and administration in order to lead the enduring proliferation of the positive follow-up effects which the World Expo made, and minimize the negative effects at large.

\section{References}

[1] Adam Finn, Tulin Erdern. The Economic Impact of a Megamulti-mall Estimation Issues in the Case of West Edmonton Mall [J]. Tourism Management, 16, 366-373 (1995).

[2] Akis S,N Peristianis and J Wamer. Residents' attitudes to tourism development: the case of cyprus[J]. Tourism Management, 17, 481-494 (1996).

[3] Breiter,D. Milman,A.Attendees' needs and service priorities in a large convention center: Application of the importanceperformance theory[J]. Tourism Management, 27, 13641370 (2006).
[4] Choong-Ki Lee, Yong-Ki Lee, Bong Koo Lee. Korea's Destination Image Formed by the 2002 World Cup[J]. Annals of Tourism Research, 32, 839-858 (2005).

[5] Dcccio C.,Baloglu S.Nonhost community resident reactions to the 2002 Winter OlymPies: The spillover impacts[J]. Journal of Travel Research, 41, 46-56 (2002).

[6] Evangelia Kasimati. Economic Aspects and the Summer Olympics: a Review of Related Research [J]. International Journal of Tourism Research, 5, 433-444 (2003).

[7] Fawzy, Ahmed. The Service Recovery Process in the Meetings, Incentives, Conventions, and Exhibitions Industry: A Conceptual Model[J]. Journal of Convention \& Event Tourism, 10, 231-242 (2009).

[8] Fredline, E., and Faulkner, B. Host Community Reactions: A cluster analysis [J]. Annals of Tourism Research, 27, 763-784 (2000).

[9] Guangquan Dai and Jigang Bao, Spatial distribution of integrated impact index of mega-event-A case study of Expo 199 Kunming[J].Chinese Geographical Science, 18, 214-223 (2008).

[10] Getz, D. Assessing the Economic Impacts of Festival and Events: research issues [J]. Journal of Applied Recreation Research, 16, 61-77 (1991).

[11] Getz, D., Timur, S. Stakeholder involvement in sustainable tourism: balancing the voices [M].Global Tourism, third edition, 230-247 (2005). 
[12] ,D.and D. G. Rutherford. Host Attitudes Toward Tourism: An Improved Structoral Model[J]. Annals of Tourism Research, 31, 495-516 (2004).

[13] Gursoy,D. and K. W. Kendall. Hosting Mega Events: Modeling Locals' Support[J]. Annals of Tourism Research, 33, 603-623 (2006).

[14] Kasimati, E. Economic Aspects and the Summer Olympics: a review of related Research [J].International Journal of Tourism Research, 5, 433-444 (2003).

[15] M. Barker, S. J. Page, D. Meyer. Modeling Tourism Crime: The 2000America's Cup[J].Annals of Tourism Research, 29, 762-782 (2002).

[16] Maurice Roche. Mega-Events and Urban Policy [J]. Annals of Tourism Research, 21, 1-19 (1995).

[17] Madrigal, R. Residents' Receptions and the Role of Government [J]. Annals of Tourism Research, 22, 86-102 (1995).

[18] Mason P and J. Cheyne. Residents' attitudes to proposed tourism development[J]. Annals of Tourism Researeh, 27, 391-411 (2000).

[19] Mc Cartney, Glenn.The CAT (Casino Tourism) and the MICE (Meetings, Incentives, Conventions, Exhibitions): Key Development Considerations for the Convention and Exhibition Industry in Macao[J]. Journal of Convention \& Event Tourism, 9, 293-308 (2008).

[20] Paul Murrell,The 2006 Data Expo of the American Statistical Association[J]. Computational Statistics, 25, 551554 (2010).

[21] Preuss, H., \& Solberg, H. Attracting Major Sporting Events: The Role of Local Residents [J]. European Sport. Management Quarterly, 6, 391-411 (2005).

[22] Ritchie, J. R. and Lyons, Marcia. Olympulse: A post-Event Assessment of Resident Reaction to the Olympic Winter Games [J]. Journal of Travel Research, 4, 14-23 (1990).

[23] Rollins,R.,Delamere,T. Measuring the social impact of festivals[J]. Annals of Tourism Researh, 34, 805-808 (2007).

[24] Small, K., D. Edwards and L. Sheridan. A Flexible Frarnework for Evaluating the Soeio-Cultural Impacts of A (Small) Festival[J]. International Journal of Event Management Research, l, 66-77 (2005).

[25] Twynam,G. D. and M. Johnston. Changes in Host Community Reations to a Special Sporting Event[J]. Current Issues in Tourism, 7, 242-261 (2004).

[26] Wang Y. C.,Daniel R. Fesenmaier. Identifying the sueccss factors of web-based marketing strategy: An investigation of convention and visitors bureaus in the United States[J]. Journal of Travel Research, 44, 239-249 (2006).

[27] Weber, Karin and Bauer, Thomas.The State of the Exhibition Industry in China[J]. Journal of Convention \& Event Tourism, 11, 2-17 (2010).

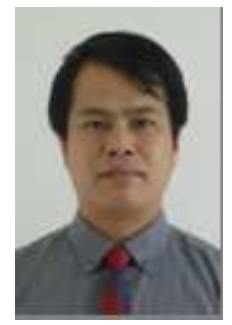

Yang

Shunyong

received the $\mathrm{PhD}$ degree in Management science from the Antai College of Economics \& Management, Shanghai JiaoTong University in 2002. $\mathrm{He}$ is currently a professor in Shanghai Institute of Technology. His research interests are in the areas of MICE Economics \& Management, routing systems, and information systems.

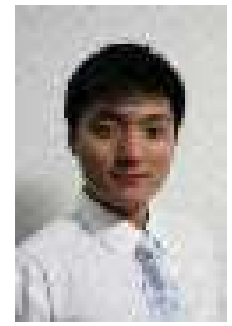

Zhao Jinjie is a junior who majors in MICE. During the study in the College of Economics \& Management, Shanghai Institute of Technology, he has shown his enthusiasm and ability in the research as the assistant of first author. His professional knowledge and experience came both from books which written by first author and own field work in the past three years.

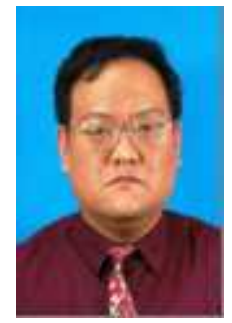

Cao Yang received Doctor of Economics from Xian Jiaotong University in 2013. He is now a standing director of the China Convention and Exhibition Society and an associate professor in Shanghai Institute of Technology. His research interests are in the areas of Regional Economics and Urbanization, SME innovation. 